\title{
Sintesis Wax Ester dari Asam Lemak Stearat secara Enzimatis Sebagai Bahan Baku Kosmetik
}

\author{
Roushandy Asri Fardani*1 dan Erin Ryantin $\mathrm{G}^{2}$ \\ ${ }^{1}$ Jurusan Analis Kesehatan, Politeknik Medica Farma Husada, Indonesia. \\ ${ }^{2}$ Fakultas MIPA, Universitas Sebelas Maret, Indonesia. \\ Corresponding author: ardaniroushandy@gmail.com
}

\section{Article history}

Received: 17 Juni 2019

Received in revised form:

9 Juli 2019

Accepted: 26 November 2019

DOI:

10.17977/um0260v3i12019p017

\section{Kata-kata kunci:}

wax ester

stearat

kosmetik

\begin{abstract}
Abstrak
Tujuan dari penelitian ini adalah untuk mensintesis wax ester dari asam lemak stearat dengan oleil alkohol, menentukan kondisi optimumnya dan untuk mengetahui berapa persen wax ester yang dihasilkan. Sintesis wax ester dilakukan secara enzimatis. Analisis wax ester secara kualitatif menggunakan KLT dan FT-IR, secara kuantitatif dengan titrasi asam basa dan penentuan kondisi optimum menggunakan variasi waktu, suhu, jumlah enzim. Berdasarkan hasil analisis KLT Rf 0,14 spektrum FT-IR (asam lemak stearat, oleil alkohol dan wax ester dapat ditarik kesimpulan bahwa wax ester dapat disintesis dari asam lemak stearat dengan oleil alkohol secara enzimatis. Kondisi optimum untuk sintesis wax ester dari asam lemak stearat yaitu selama 2 jam, pada suhu $40{ }^{\circ} \mathrm{C}$, dengan jumlah enzim lipase 0,15 gram, pada perbandingan asam stearat : oleil alkohol $=1: 3$ dan dengan $n$-heksana sebagai pelarut terbaiknya. Adapun persen konversi yang diperoleh yaitu sebesar $94 \%$.
\end{abstract}

\begin{abstract}
The purpose of this study is to synthesize wax ester from fatty acid stearic with oleil alcohol, determine the optimum conditions and to find out what percentage of wax ester is produced. Wax ester synthesis is carried out enzymatically. Qualitative wax ester analysis using TLC and FT-IR, quantitatively by acid-base titration and determination of optimum conditions using a variation of time, temperature, number of enzymes. Based on the results of the TLC analysis obtained the Rf value of 0.14, FT-IR spectrum of stearic fatty acids, oleil alcohol and wax ester can be concluded that wax ester can be synthesized from fatty acid stearic with oleil alcohol enzymatically. The optimum conditions for wax ester synthesis from stearic fatty acid for 2 hours, at $40^{\circ} \mathrm{C}$, with a lipase amount of $0.15 \mathrm{grams}$, in the ratio of stearic acid: oleil alcohol = 1: 3 and with $n$-hexane as the best solvent. The percentage of conversion obtained is $94 \%$.
\end{abstract}

\section{PENDAHULUAN}

Indonesia merupakan Negara yang kaya dengan sumber daya alam, baik flora maupun fauna. Di Indonesia dikenal beberapa jenis flora penghasil minyak terbesar di dunia. Dimana sebagian dari produksi minyak-minyak tersebut digunakan sebagai bahan baku untuk keperluan industri. Salah satu industri lanjutan dari produk minyak yang berasal dari tumbuhan adalah industri oleokimia. Industri ini memproduksi asam lemak, metil ester, dan fatty alcohol dimana produk-produk tersebut berpotensi sebagai bahan baku untuk sintesis wax ester.

Wax ester merupakan ester rantai panjang yang diperoleh dari asam lemak dan alkohol rantai panjang dengan jumlah karbon 12 atau lebih. Wax ester adalah bahan penting dalam formulasi kosmetik seperti pembersih, kondisioner, dan juga pelembab. Wax esters juga digunakan dalam obat-obatan yaitu sebagai antibusa dalam produksi penisilin, sebagai pengatur pelepasan obat. Selain itu, wax esters juga 
digunakan sebagai pelumas, bahan plastik dan semir. Penggunaan yang beranekaragam ini mengacu ke sifat-sifat unik dari wax esters yaitu mampu melembabkan tanpa menimbulkan rasa berminyak (Gunawan, 2008).

Salah satu sumber bahan baku untuk mensintesis wax ester yang ketersediaannya melimpah adalah asam stearat. Asam stearat atau yang dikenal juga dengan asam oktadekanoat mempunyai rumus kimia $\mathrm{CH}_{3}\left(\mathrm{CH}_{2}\right)_{16} \mathrm{COOH}$. Asam stearat banyak terkandung pada minyakminyak yang berasal dari tumbuhan. Seperti misalnya pada minyak biji ketapang, minyak kelapa, minyak jagung, minyak kemiri (Rahman dkk, 2003). Adapun kandungan terbesar dari asam stearat pada minyak-minyak tersebut yaitu dari minyak biji ketapang sebesar 4,13\% (Matos et al., 2009), minyak kelapa sawit sebesar 3,64,7\%, minyak kemiri sebesar $6,7 \%$, minyak biji jagung sebesar 4,9\% (Ketaren,1986). Asam lemak stearat juga terdapat pada kacangkacangan seperti kacang tanah $(8,11 \%)$, kacang merah (2,86\%), kacang hijau (5,88\%) (Danuarsa,2006), dan kacang kedelai $(6,51 \%)$ (Paterson et al,2006). Dari perolehan rendemen asam stearat pada minyak-minyak nabati yang cukup besar, maka asam stearat dapat digunakan sebagai salah satu bahan untuk mensintesis wax ester.

Wax ester bisa disintesis dengan menggunakan metode kimiawi dan enzimatis, namun untuk mensintesis wax ester secara kimiawi mempunyai kelemahan yang berhubungan dengan penggunaan energi dan produk samping yang tidak dikehendaki dan juga kurang ramah terhadap lingkungan Elisabeth dkk,1998) sedangkan metode enzimatis menawarkan kondisi reaksi yang ringan dan prosesnya berlangsung ramah dengan lingkungan dan senyawa yang dihasilkan tidak berbahaya untuk aplikasi selanjutnya serta menghasilkan produk yang murni dengan prosedur sederhana. Penelitian ini bertujuan untuk mengetahui kondisi optimum sintesis wax ester dari asam lemak stearat secara enzimatis menggunakan enzim lipase dan untuk mengetahui berapa persen wax ester yang dihasilkan pada kondisi optimum..

\section{METODE}

Jenis penelitian ini merupakan jenis penelitian eksperimental. Sampel dalam penelitian ini adalah asam lemak stearat yang dikonversikan menjadi wax ester. Variabel terikat pada penelitian ini adalah wax ester dan variabel bebas dalam penelitian ini adalah jumlah rasio molar asam stearat dengan oleyl alkohol, jumlah lipase, suhu dan waktu. Adapun tahapan tahapan yang dilakukan pada penelitian ini adalah tahap 1: tahap sintetis wax ester, tahap 2: analisa wax ester meliputi analisa kualitatif dengan kromatografi lapis tipis dan FTIR serta analisa kuantitatif dengan metode titrasi asam basa yang menggunakan $\mathrm{NaOH} 0,01 \mathrm{M}$ sebagai titernya. Metode ini digunakan untuk mengetahui persen konversi dari wax ester yang terbentuk. Dari hasil titrasi diketahui jumlah (volume) $\mathrm{NaOH}$ $0,01 \mathrm{M}$ yang bereaksi dengan wax ester pada titik akhir titrasi. Untuk menentukan persen konversi wax ester hasil sintesis secara enzimatis menggunakan enzim lipase dengan menggunakan persamaan 1 (Radzi, et al., 2008):

$\%$ wax ester $=\frac{\mathrm{V}_{\mathrm{NaOH}}(\text { tanpa enzim })-\mathrm{V}_{\mathrm{NaOH}}(\text { enzim })}{\mathrm{V}_{\mathrm{NaOH}}(\text { tanpa enzim })} \times 100 \%$ (1)

Prinsip perhitungan persen konversi dengan menggunakan persaamaan di atas yaitu untuk mengetahui dari 95\% kemurnian bahan (asam stearat) yang digunakan, berapa persen yang dapat dikonversikan menjadi wax ester. Analisis kualitatif wax ester dilakukan dengan uji Kromatografi Lapis Tipis (KLT) dan FT-IR.

\section{HASIL DAN PEMBAHASAN}

Hasil analisis kualitatif dengan menggunakan KLT merupakan uji senyawa kimia yang didasarkan dengan perbedaan adsorbsi pada fase diam (silika gel) terhadap fase gerak (eluen) dimana eluen yang digunakan pada penelitian ini adalah $n$-heksana, Etil asetat, dan asam asetat. Identifikasi noda yang dihasilkan oleh plat KLT dilakukan dengan menggunakan uap iod. Pola-pola pemisahan yang dihasilkan pada kromatogram dapat dilihat pada Gambar 1.

Pada spot pertama dari analisa KLT (Gambar 1.c) diperoleh nilai $\mathrm{Rf} 0,23$ yang diidentifikasikan sebagai oleil alkohol karena nilai Rf yang diperoleh mendekati nilai $\mathrm{Rf}$ dari oleil alkohol (Gambar 1.a) yaitu 0,22. Pada spot kedua dari Gambar c mempunyai nilai Rf 0,14 dan nilai Rf tersebut sama seperti nilai Rf dari ester diidentifikasikan sebagai ester karena nilai $\mathrm{Rf}$ yang diperoleh sama dengan nilai $\mathrm{Rf}$ pada ester standar.

Analisis FT-IR dilakukan dengan membandingkan spektrum FT-IR oleil stearat hasil sintesis, oleil alkohol dan asam stearat 
murni. Analisis FT-IR dilakukan dengan membandingkan spektrum FT-IR oleil stearat hasil sintesis, oleil alkohol dan asam stearat murni. Tujuan dari dilakukannya analisis dengan membandingkan spektrum FTIR ini adalah untuk mengetahui berhasil atau tidaknya penelitian sintesis wax ester secara enzimatis ini. Berdasarkan hasil spektrum FT-IR pada Gambar spektrum asam stearat dapat dilihat bahwa pada bilangan gelombang 2915,20-2848,67 $\mathrm{cm}^{-1}$ terdapat peak yang menandakan adanya gugus $\mathrm{OH}$ untuk karboksilat dan pada bilangan gelombang 1693,38 terdapat satu pita yang dimiliki oleh regangan $\mathrm{C}=\mathrm{O}$ untuk karboksilat.

Pada gambar spektrum FT-IR oleil stearat di atas (gambar 4.8) dapat diketahui bahwa pada bilangan gelombang $3342,41 \mathrm{~cm}^{-1}$ terdapat regangan $\mathrm{OH}$ alkohol. Pada strech bilangan gelombang 2924,85-2853,49 $\mathrm{cm}^{-1}$ terdapat gugus fungsi $\mathrm{C}-\mathrm{H}$ alkil. Pada bilangan gelombang $3004,89 \mathrm{~cm}-1$ merupakan regangan $=\mathrm{C}-\mathrm{H}$. Pada daerah finger print yaitu dengan bilangan gelombang $1656,74 \mathrm{~cm}-1$ dianggap sebagai gugus fungsi $\mathrm{C}=\mathrm{C}$. Jadi dari hasil analisis secara kuantitatif dengan titrasi asam basa, analisa secara kualitatif dengan KLT serta analisis FTIR yang membandingkan spektrum FTIR asam lemak stearat, oleil alkohol dan wax ester hasil sintesis dapat disimpulkan bahwa wax ester (oleil stearat) dapat disintesis dari asam lemak stearat.

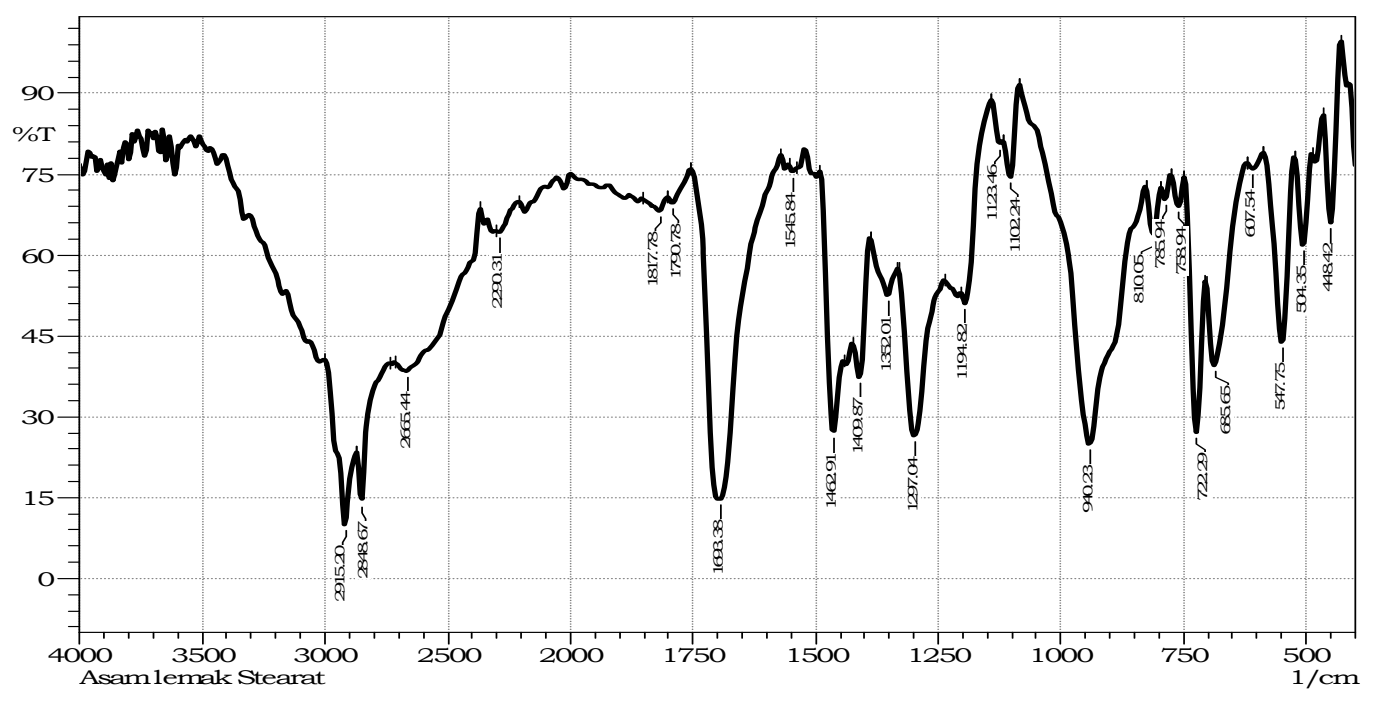

Gambar 2. Spektrum FTIR dari Asam Lemak Stearat

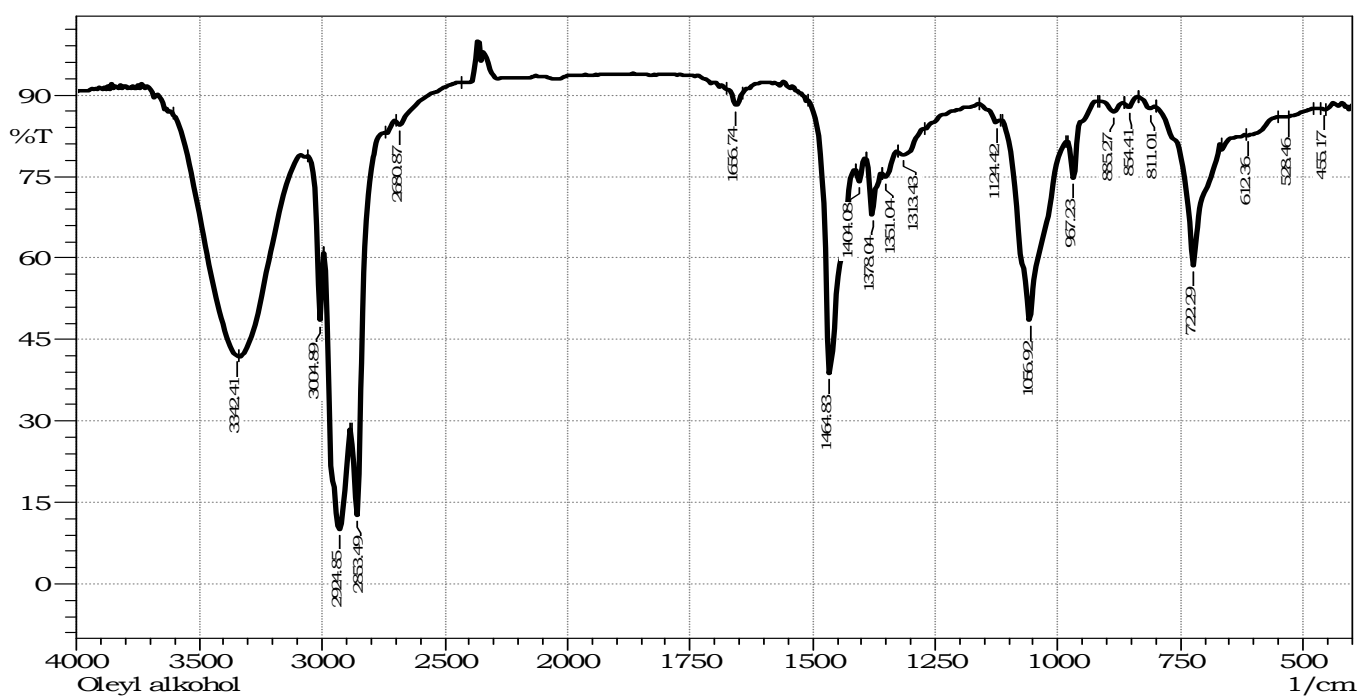

Gambar 3. Spektrum FT-IR dari oleil stearat 

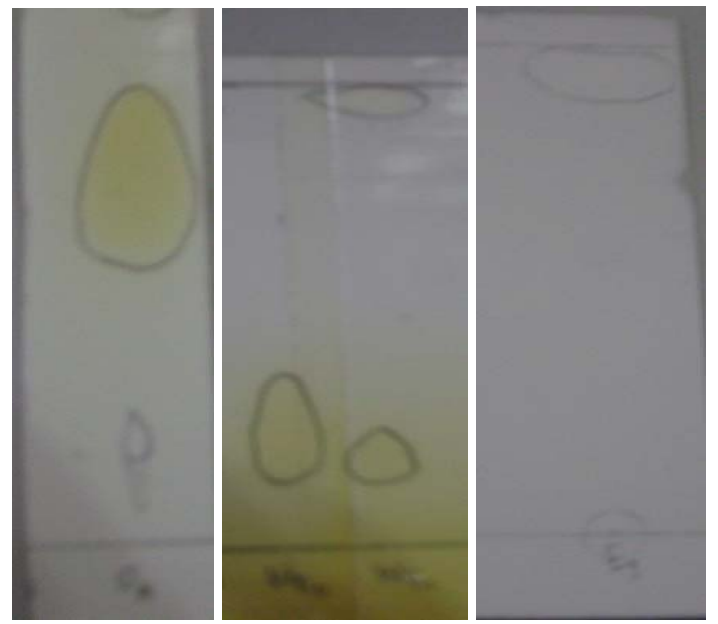

Gambar 1. a: Oleil alkohol, b: Oleil stearat + enzim (sebelum dishaker), c: Oleil stearat + enzim (setelah dishaker),

\section{Penentuan Kondisi Optimum Untuk Sintesis wax ester dari asam lemak}

Waktu merupakan indikator yang tepat untuk mengetahui kemampuan enzim dan kemajuan reaksi. Enzim yang memiliki kemampuan yang baik adalah enzim yang mempunyai waktu yang pendek untuk mendapatkan hasil yang optimal. Semakin pendek waktu yang dibutuhkan untuk mendapatkan hasil yang optimal, maka semakin sedikit biaya yang dikeluarkan. Berdasarkan Tabel 1 dapat dilihat jumlah dari oleil stearat yang dihasilkan berdasarkan waktu yang digunakan, jumlah oleil stearat yang dihasilkan semakin meningkat seiring bertambahnya waktu yang digunakan dan mencapai kondisi optimumnya pada waktu 2 jam (120 menit). Peningkatan hasil dengan bertambahnya waktu reaksi tersebut terjadi karena adanya penambahan jumlah substrat yang dapat diubah menjadi produk.

Berdasarkan waktu reaksi optimum yang diperoleh dari tahap reaksi esterifikasi enzimatis variasi waktu, maka digunakan waktu reaksi selama 2 jam untuk tahap reaksi selanjutnya, yaitu tahap optimasi suhu. Untuk menentukan suhu optimum pada sintesis oleil stearat digunakan variasi suhu $30,35,40,45,50$ dan $55 \mathrm{oC}$. Berdasarkan tabel 2, oleil stearat yang dihasilkan semakin meningkat seiring dengan kenaikan suhu yang terjadi. Pada suhu $40^{\circ} \mathrm{C}$ diperoleh kadar oleil stearat yang maksimum, dan setelah lewat dari suhu $40^{\circ} \mathrm{C}$ (yang merupakan suhu optimumnya) terjadi penurunan kadar oleil stearat. Enzim lipase sangat aktif pada kisaran suhu 30 sampai $40^{\circ} \mathrm{C}$ sehingga mungkin jika diperlakukan pada suhu yang lebih tinggi atau diatas $40^{\circ} \mathrm{C}$, maka enzim tersebut akan mengalami denaturasi.

Tabel 1. Pengaruh waktu inkubasi terhadap persentase hasil sintesis asam lemak stearat

\begin{tabular}{ccc}
\hline No. & Waktu (menit) & $\begin{array}{c}\text { Konversi oleil } \\
\text { stearat (\%) }\end{array}$ \\
\hline 1 & 5 & 72 \\
2 & 30 & 73 \\
3 & 60 & 75 \\
4 & 120 & 83 \\
5 & 180 & 80 \\
6 & 240 & 71 \\
7 & 300 & 63 \\
8 & 360 & 63 \\
\hline
\end{tabular}

Tabel 2. Pengaruh suhu terhadap persentase hasil sintesis asam lemak stearat

\begin{tabular}{ccc}
\hline No. & Suhu $\left({ }^{\circ} \mathbf{C}\right)$ & $\begin{array}{c}\text { Konversi oleil } \\
\text { stearat }(\%)\end{array}$ \\
\hline 1 & 30 & 78 \\
2 & 35 & 83 \\
3 & 40 & 83 \\
4 & 45 & 78 \\
5 & 50 & 77 \\
6 & 55 & 76 \\
\hline
\end{tabular}

Perlakuan tahap ketiga ini adalah untuk melihat pengaruh terhadap oleil stearat yang dihasilkan dari perbedaan jumlah katalis enzim yang diberikan dan mencari persentase katalis terhadap substrat yang optimum. Variasi jumlah enzim yang digunakan yaitu 0,$05 ; 0,1 ; 0,15 ; 0,2$; 0,$25 ; 0,3$ gram. Dari segi penerapan, jumlah enzim lipase yang digunakan harus sekecil mungkin untuk mendapatkan hasil semaksimal mungkin. Karena bagaimanapun, semakin tinggi jumlah enzim lipase yang dipakai, maka semakin tinggi pula biaya yang dipakai. Dari tabel 3 dapat dilihat jumlah produk oleil stearat yang dihasilkan semakin meningkat seiring dengan penambahan jumlah lipase. Hal ini disebabkan karena semakin banyak jumlah katalis yang ditambahkan kedalam reaksi esterifikasi, sehingga mencapai jumlah optimumnya. Maka akan semakin mempercepat reaksi dan mampu menghasilkan produk yang lebih banyak.

Variasi perbaningan mol yang dilakukan antara oleil alkohol dengan asam stearat adalah $1: 1,1: 2,1: 3,2: 1,3: 1$. Variasi perbandingan mol ini dilakukan karena reaksi esterifikasi-enzimatis merupakan reaksi reversibel, sehingga jumlah 
reaktan ditambah maka akan memperbesar jumlah produk. Rasio molar asam stearat merupakan salah satu parameter yang dapat mempengaruhi persentase (yield) dari ester yang dihasilkan. Berdasarkan teori, pada reaksi esterifikasi $1 \mathrm{mmol}$ asam stearat memerlukan 1 mmol alkohol. Sehingga apabila alkohol berlebih dapat mengalihkan kesetimbangan ke arah pembentukan ester, karena reaksi esterifikasi merupakan reaksi reversibel (Susanto, 2008).

Tabel 3. Pengaruh jumlah enzim terhadap persentase hasil sintesis asam lemak stearat

\begin{tabular}{ccc}
\hline No. & Jumlah enzim (g) & $\begin{array}{c}\text { Konversi oleil } \\
\text { stearat (\%) }\end{array}$ \\
\hline 1 & 0,05 & 75 \\
2 & 0,10 & 79 \\
3 & 0,15 & 83 \\
4 & 0,20 & 79 \\
5 & 0,25 & 79 \\
6 & 0,30 & 79 \\
\hline
\end{tabular}

Tabel 4. Pengaruh rasio molar asam stearat : oleil alkohol

\begin{tabular}{ccc}
\hline No. & Rasio & $\begin{array}{c}\text { Konversi oleil } \\
\text { stearat (\%) }\end{array}$ \\
\hline 1 & $1: 1$ & 83 \\
2 & $1: 2$ & 87 \\
3 & $2: 1$ & 89 \\
4 & $1: 3$ & 96 \\
5 & $3: 1$ & 82 \\
\hline
\end{tabular}

Tabel 5. Pengaruh pelarut terhadap pembentukan oleil stearat

\begin{tabular}{ccc}
\hline No. & Pelarut & $\begin{array}{c}\text { Konversi oleil } \\
\text { stearat (\%) }\end{array}$ \\
\hline 1 & DCM & 77 \\
2 & Etanol & 75 \\
5 & $n$-heksana & 83 \\
\hline
\end{tabular}

Dari ketiga macam pelarut yang digunakan yaitu $n$-heksana, DCM dan etanol diperoleh pelarut $n$-heksana sebagai pelarut yang paling baik dalam penelitian ini karena menghasilkan persen yield oleil stearat sebesar 83\%. Disamping alasan itu, $n$-heksana dipilih sebagai pelarut untuk oleil stearat didasarkan atas pertimbangan bahwa pelarut yang terbaik untuk sintesis asam lemak adalah n-heksana, lebih spesifik lagi dari penelitian Gunawan (2008) dilaporkan bahwa $n$-heksana merupakan pelarut yang optimal untuk reaksi yang menggunakan lipase sebagai katalisnya. Pemilihan $n$-heksana sebagai pelarut yaitu karena $n$-heksana memberikan hasil yang terbaik untuk sintesis asam lemak dari minyak nabati. Ketika ketiganya dicampurkan (dengan enzim), lipase tidak tercampur dengan larutan oleil stearat. Hal tersebut disebabkan karena lipase yang digunakan adalah lipase sintetis merupakan katalis yang bersifat polar dan mempunyai kelarutan yang tinggi. karena lipase sudah berbentuk immobilized lipase, maka lipase menjadi tidak larut dan berada diantara lapisan n-heksana.

Tabel 6. Kondisi optimum sintesis oleil stearat dari asam lemak stearat dan oleil alkohol

\begin{tabular}{cll}
\hline No. & Parameter & \multicolumn{1}{c}{ Kondisi } \\
\hline 1 & Waktu reaksi & 2 jam (120 menit) \\
2 & Suhu & $40^{\circ} \mathrm{C}$ \\
3 & Jumlah enzim (lipase) & $0,15 \mathrm{~g}$ \\
4 & Rasio molar asam & $1: 3$ \\
& stearat : oleil alkohol & \\
5 & Pelarut Terbaik & $n$-heksana \\
\hline
\end{tabular}

Tahap sintesis setelah mencapai kondisikondisi optimum diperoleh kadar oleil stearat sebesar 94\%. Penelitian kali ini merupakan proses esterifikasi antara asam lemak dan alkohol yang akan membentuk ester serta air sebagai produk sampingnya, dan reaksi ini merupakan reaksi yang reversibel.

\section{KESIMPULAN}

Wax ester (oleil stearat) dapat disintesis dari asam lemak stearat. Kondisi optimum yang diperoleh dari sintesis oleil stearat dari asam lemak stearat adalah pada waktu 2 jam dan suhu $40^{\circ} \mathrm{C}$. jumlah lipase 0,15 gram dengan perbandingan asam stearat (mmol):oleil alkohol (mmol) adalah 1:3 dan pelarut $n$-heksana. Hasil konversi optimum yang dapat dicapai yaitu sebesar $94 \%$.

\section{DAFTAR RUJUKAN}

Chen, J.P. dan J.B.Wang, 1997,Wax Ester Synthesis by Lipase -Catalyzed Esterification with fungal cells immobilized on cellulose biomass support particles, Enz, Microb. Technol Journal.

Danuarsa, 2006, Analisis Proksimat dan Asam Lemak Pada Beberapa Komoditas 
Kacang-kacangan, Buletin Teknik Pertanian Vol.11 no. 1.

Fessenden, Ralph J., 1997.Kimia Organik Edisi Ke Tiga, Jakarta : Erlangga.

Gunawan, E.R dan Suhendra, Dedy, 2008, Synthesis of Wax Ester From Palm Kernel Oil Catalyzed by Lipase, Jurnal Matematika dan Sains.

Gutiěrrez, C. et al., 2007, Relation Between Lipase Structure and Their Catalytic Ability to hydrolyse Triglyserides and Phospholipids, ScienceDirect,

Hart, H., 2003, Kimia Organik Suatu Kuliah Singkat, Edisi 11, Terjemahan Seminar Achmadi, Jakarta: Erlangga.

Hilyati., Wuryaningsih dan Irawan, Yan, 2003, Sintesa Ester Asam Lemak Dengan Alkohol Sekunder Sebagai Emollient, Pusat Penelitian Kimia-LIPI, p : C-127C135.

Ketaren, 1986, Pengantar Teknologi Minyak dan Lemak Pangan, Jakarta : UI Press.

Khopkar, 2008, Konsep Dasar Kimia Analitik, Jkarta: UI Press.

Kurniasih, Eka, 2008, Pemanfaatan Asam Lemak Sawit Distilat Sebagai Bahan Baku Dietanolamida Menggunakan Lipase, Jurusan Kimia Fakultas MIPA Universitas Sumatera Utara Medan.

Kusmiyati, 2008, Reaksi Katalitis Esterifikasi Asam Oleat Dan Metanol Menjadi Biodiesel Dengan Metode Destilasi Reaktif, Jurusan Teknik Kimia Fakultas Teknik Universitas Muhamadiyah Surakarta.

Matos, L., Nzikou, J.M., Kimbonguila, A., Ndangui, C.B., Pambou-Tobi, N.P.G., Abena, A.A., Silou, Th., Scher, J dan Desobry, S, 2009, Composition and Nutritional Properties of Seeds and Oil From Terminalia catappa L, Advance Journal of Food Science and Technology 1.
Patterson, M., Wyborney, P., Blumfield, A. 2006. Soybean Oil. http://www.wsu.edu/ gmhyde/433_web_p ages/433Oil-webpages/Soy/soybean1.html. Diakses tanggal 11 oktober 2010.

Primadiati, Rachmi, 2001, Kecantikan, Kosmetika dan Estetik,. Jakarta : Gramedia.

Rahman, Abdul, M.B., Yong, K.C., Basri, M., Rahman, Abdul, R.N.Z., Razak, C.N.A dan Salleh, A.B, 2003 Synthesis of Oleyl Oleat, a Liquid Wax Ester, using Lipozime, Malaysian Journal of Chemistry, Vol.3, No.1, 0046-0050.

Rizki, Alfaria, et. al., 2008, Pengaruh Kondisi Sperasi Reaksi Esterifikasi Enzimatis Gliserol dengan Asam Laurat Pada Pembentukan Agen Pengemulsi, Jurusan Teknik Kimia, Fakultas Teknik, Universitas Diponegoro.

Susanto, Bambang, 2008, Reaksi Esterifikasi Asam Oleat dengan Alkohol Rantai Panjang Berkatalis HPW, Jurusan Teknik Kimia, Fakultas Teknik Universitas Indonesia Jurnal Sains.

Tarigan, Br Juliati, 2002, Ester Asam Lemak, jurusan Kimia, MIPA Digital Library USU, Universitas Sumatera Utara.

Tranggono, Retno, 1992, Kiat Apik Menjadi Sehat dan Cantk,. Jakarta: Gramedia Pustaka Utama.

Vakhlu, J. dan Avneet K., 2006, Yeast Lipases: Enzyme Purification, Biochemical Proparties and Gene Cloning, Electronic Journal and Biotechnology,9, 1.

Young, A., 1974, Practical Cosmetic Science, London Mills and Boon Limited. 